\title{
COMPLEX INTERACTIONS OF FISH, SNAILS, AND LITTORAL ZONE PERIPHYTON
}

\author{
Elizabeth Walker McCollum, ${ }^{1,4}$ Larry B. Crowder, ${ }^{2,5}$ And S. Andy McCollum ${ }^{3}$ \\ ${ }^{1}$ Department of Zoology, North Carolina State University, Raleigh, North Carolina 27695 USA \\ ${ }^{2}$ Nicholas School of the Environment and Department of Zoology, Duke University Marine Laboratory, \\ 135 Duke Marine Lab Road, Beaufort, North Carolina 28516-9721 USA \\ ${ }^{3}$ Department of Biology, University of Michigan, Ann Arbor, Michigan 48109 USA
}

\begin{abstract}
This study examines the interaction of predation and resource-based effects of fish on freshwater periphyton communities. Current theory predicts that fish primarily influence periphyton communities by controlling herbivore densities. But fish may also influence algal communities by increasing available nutrients via nutrient recycling. To separate these effects and to determine their relative importance, we made a number of specific predictions based on the literature and tested these predictions by manipulating the presence and absence of the molluscivorous redear sunfish, Lepomis microlophus, and snails, Physella heterostropha, in a replicated factorial experiment. We examined the effects of fish on nutrient concentrations in the water and on snail grazing activity and life history traits. We also evaluated the effect of fish and snails on cell number, biovolume, cell size, and growth form of all periphyton, green algae, diatoms, and blue-green algae. Concentrations of phosphorus and nitrogen in the water were significantly higher in the presence of fish, but this had little effect on total periphyton. Although fish had only visual and waterborne (olfactory) contact with snails, their presence inhibited snail reproduction and/ or increased mortality of small snails such that twice as many snails were produced in the absence of fish. Snail grazing activity was six times higher in the absence of caged fish than in their presence. In the absence of fish, snails reduced periphyton cell number and increased the average size of the periphyton cells, primarily through effects on green algae. Snails reduced the biovolume of diatoms and blue-green algae. Fish also reduced diatom biovolume by decreasing the average cell size of diatoms. Snails increased the proportion of gelatinous colonies in the periphyton. Previous research suggests that fish have a positive indirect effect on algae by removing grazers. Fish can augment this effect by negatively affecting snail life history traits and by reducing grazing activity. In addition, fish may have an important but less obvious direct effect on algae via changing nutrient concentrations and possibly altering competitive outcomes among taxa and growth forms.
\end{abstract}

Key words: algae; direct effects; grazing; fish; indirect effects; Lepomis; littoral zone; North Carolina; nutrient recycling; periphyton; predation; Physella; snails.

\section{INTRODUCTION}

The interaction of predation and resource limitation as factors determining the structure and function of aquatic communities is not well understood (Crowder et al. 1988). Traditionally, ecologists have considered either the importance of resource-based or predatorbased forces to the structure and function of food webs (Dillon and Rigler 1974, Elwood et al. 1981, Lamberti and Resh 1983, Northcote 1988) but clearly both predation and nutrients may act simultaneously (Carpenter et al. 1987, Stewart 1987, Vanni 1987, Leibold 1989, McCormick and Stevenson 1991, Hansson 1992, Hunter and Price 1992, Rosemond et al. 1993).

Cascading effects of predators can influence the

Manuscript received 17 June 1996; revised 18 July 1997; accepted 22 July 1997; final version received 26 September 1997.

${ }^{4}$ Present address: Department of Biology, Cornell College, 600 First Street West, Mt. Vernon, Iowa 52314-1098.

${ }^{5}$ Address reprint requests to this author. structure and function of the community (Paine 1980, Carpenter et al. 1985, 1987, McQueen et al. 1986, Vanni and Findlay 1990), but the evidence for consistent predator-based effects is still equivocal (Carpenter and Kitchell 1992, 1993a, DeMelo et al. 1992, Vanni 1996). Clearly, nutrients are also an important determinant of algal biomass and community structure (Tilman et al. 1982, Sommer 1983, Peters 1986, Carney et al. 1988, Sterner 1989). Therefore any model of predator-based effects should include not only the effect of removing herbivores but also the effect of nutrient regeneration.

The pelagic zone and phytoplankton have been the focus of most research on cascading predator effects, but data increasingly point to the importance of the littoral zone and periphyton to the structure and function of lake communities. Estimates of primary production suggest that periphyton production is more than adequate to support littoral grazers and predators (Burkholder and Wetzel 1989a, Wetzel 1990). In addition, recent efforts at formulating pelagic nutrient 
TABLE 1. Hypotheses motivating the study of littoral-zone interactions of snails, fish, and algae, with predictions and associated support.

\begin{tabular}{|c|c|c|}
\hline & Predictions and support & $\begin{array}{l}\text { Expected relative } \\
\text { abundance } \dagger\end{array}$ \\
\hline \multicolumn{3}{|c|}{$\begin{array}{l}\text { Hypothesis 1: If fish affect periphyton by consuming snails and reducing grazing pressure on the algae (indirect trophi } \\
\text { cascade effect), then }\end{array}$} \\
\hline A) & $\begin{array}{l}\text { Periphyton biovolume and cell number will be reduced in the presence } \\
\text { of snails compared to non-snail treatments (Cuker 1983, McCormick } \\
\text { and Stevenson 1989, Mulholland et al. 1991). }\end{array}$ & $\begin{array}{l}\text { Biovolume: } \mathrm{S}=\mathrm{FS}<\mathrm{F}=\mathrm{A} \\
\text { Cell number: } \mathrm{S}=\mathrm{FS}<\mathrm{F}=\mathrm{A}\end{array}$ \\
\hline B) & $\begin{array}{l}\text { In snail treatments, average cell size will decrease relative to non- } \\
\text { snail treatments (Cuker 1983, McCormick and Stevenson 1991, Martin } \\
\text { et al. 1992). }\end{array}$ & Avg. cell sizes: $\mathrm{S}=\mathrm{FS}<\mathrm{F}=\mathrm{A}$ \\
\hline C) & $\begin{array}{l}\text { Adnate algal cells will make up a greater proportion of the community } \\
\text { in snail treatments compared to non-snail treatments (Brönmark 1989, } \\
\text { McCormick and Stevenson 1991, Steinman et al. 1991). }\end{array}$ & Percentage adnate: $\mathrm{S}=\mathrm{FS}>\mathrm{F}=\mathrm{A}$ \\
\hline D) & $\begin{array}{l}\text { Inedible algae, particularly gelatinous colonial greens and bluegreens, } \\
\text { will comprise a greater percentage of the community in the presence } \\
\text { of snails than in non-snail treatments (Porter 1977, Brönmark 1989, } \\
\text { Steinman et al. 1992). }\end{array}$ & $\begin{array}{l}\text { Percentage gelatinous colonies and } \\
\text { percentage bluegreens: } \mathrm{S}=\mathrm{FS}>\mathrm{F}=\mathrm{A}\end{array}$ \\
\hline \multicolumn{3}{|c|}{ Hypothesis 2: If fish affect periphyton by increasing the rate of nutrient supply through excretion (direct effect), then } \\
\hline & $\begin{array}{l}\text { Nutrient concentrations will be higher in the presence of fish than in } \\
\text { their absence (Hansson et al. 1987, Brabrand et al. 1990, Kraft 1992). }\end{array}$ & $\mathrm{TP}$ and $\mathrm{TN}: \mathrm{F}=\mathrm{FS}>\mathrm{S}=$ \\
\hline & $\begin{array}{l}\text { Periphyton biovolume and cell number will be greater in the presence } \\
\text { of fish (Drenner et al. 1986, Hambright et al. 1986, McCormick 1990). }\end{array}$ & $\begin{array}{l}\text { Biovolume: } \mathrm{F}=\mathrm{FS}>\mathrm{S}=\mathrm{A} \\
\text { Cell number: } \mathrm{F}=\mathrm{FS}>\mathrm{S}=\mathrm{A}\end{array}$ \\
\hline & $\begin{array}{l}\text { In fish treatments, average cell size will decrease (Reinertsen et al. } \\
\text { 1986). }\end{array}$ & Avg. cell size: $\mathrm{F}=\mathrm{FS}<\mathrm{S}=\mathrm{A}$ \\
\hline & $\begin{array}{l}\text { Filamentous and upright growth forms will make up a greater pro- } \\
\text { portion of the community in fish treatments (Littler 1980). }\end{array}$ & Percentage filamentous: $\mathrm{F}=\mathrm{FS}>\mathrm{S}=\mathrm{A}$ \\
\hline & $\begin{array}{l}\text { Bluegreens and large greens will comprise a greater percentage of the } \\
\text { periphyton community in the presence of fish (Stevenson et al. 1985, } \\
\text { Reinertsen et al. 1986, Threlkeld 1988, Vanni and Findlay 1990, Mun- } \\
\text { die et al. 1991). }\end{array}$ & $\begin{array}{l}\text { Percentage bluegreens and greens: } \\
\mathrm{F}=\mathrm{FS}>\mathrm{S}=\mathrm{A}\end{array}$ \\
\hline
\end{tabular}

$\dagger$ Letters in abundance column represent the following treatments: $\mathrm{A}=$ algae only (no snails or fish), $\mathrm{F}=$ fish present, $\mathrm{S}=$ snails present, $\mathrm{FS}=$ fish and snails present.

budgets suggest that fish translocate energy and materials from the littoral to the pelagic habitat (Lodge et al. 1988, Hecky and Hesslein 1995, Schindler et al. 1996, Vanni 1996).

The trophic cascade hypothesis has recently been evaluated in freshwater littoral food webs (Brömark et al. 1992, Martin et al. 1992, Brönmark 1994). In these studies, molluscivorous fish reduced the abundance of grazing snails and increased periphyton biomass. However, fish also release nutrients as a product of their foraging, and these nutrients can influence algal biomass and community structure. We conducted an experiment to examine the relative contributions of predation and nutrient release by fish to the observed trophic cascade in the littoral zone. Using the molluscivorous redear sunfish, Lepomis microlophus, and the snail Physella heterostropha, we attempted to separate the resource-based and predation-based effects of fish on periphyton. We tested the following a priori hypotheses regarding the effects of fish and snails on algal biovolume, cell size, cell number, community composition, and cell morphology (see Table 1 for specific predictions and literature support). Hypothesis 1: Fish indirectly influence periphyton by consuming snails, thereby reducing grazing pressure on the algae. Hypothesis 2: Fish directly influence periphyton com- munities by increasing nutrient concentrations; i.e., by converting nutrients previously sequestered in snail biomass into a dissolved, highly available form. Although we expect both mechanisms to occur simultaneously in nature, observing the effects both separated and in concert enabled us to determine their individual importance, as well as the importance of their interaction, to periphyton.

\section{Methods}

\section{Experimental design and apparatus}

To examine the predation-based and resource-based effects of fish on periphyton, we conducted a 6-wk experiment at North Carolina State University's Aquatic Research Facility (Raleigh, North Carolina) from mid-June through early August 1992. Experimental units consisted of 24 aquaria, each of which held 72 L. Each tank was covered with a lid made of white plastic "no-seeum" netting (250- $\mu \mathrm{m}$ mesh), which prohibited the emigration of snails and immigration of all but a few small insects (chironomids). The aquaria were placed outdoors in two water baths (each $2.5 \mathrm{~m}$ in diameter), which acted as thermal buffers. We recorded daily maximum and minimum temperatures (average maximum $=30^{\circ} \mathrm{C}$, average minimum $=26^{\circ} \mathrm{C}$, 
and range $23^{\circ}-33^{\circ} \mathrm{C}$ ). On days when water temperatures rose above $31^{\circ} \mathrm{C}$, we covered the experiment with shade cloth from 1130 in the morning to 1500 in the afternoon to reduce thermal loading. Each aquarium had a plastic divider placed such that one side of the aquarium held about one-third of the aquarium volume and the other side held the remaining two-thirds. The dividers were perforated with $1-\mathrm{mm}$ holes positioned $5 \mathrm{~mm}$ apart to allow water movement between the two compartments.

We manipulated the presence of redear sunfish and snails in a $2 \times 2$ factorial experiment. Both species are common in North Carolina freshwater littoral zones. All treatments contained a periphyton assemblage. The four treatments in the factorial were algae, snails, fish, and (fish + snail). The experiment was blocked by water bath; treatments were replicated twice within each block, resulting in four replicates per treatment. Treatments were assigned randomly within block.

Redears were obtained from a local fish hatchery, and snails were collected from Yates Mill Pond, Wake County, North Carolina. Mean fish size initially was $86 \mathrm{~mm}$ standard length (SL) and $16 \mathrm{~g}$. We used the smallest size of redear that was still able to consume the largest snails in our tanks. Mean snail length (length of longest shell axis) was initially $3.7 \mathrm{~mm}$ (range 1.5$7.5 \mathrm{~mm}$ ). In treatments with fish, one redear was placed in the smaller section of the aquarium; in treatments with snails, 45 snails were added to the larger section. Thus, when fish and snails were in the same aquarium, they were separated by a plastic divider. A pilot experiment demonstrated that if fish had direct access to the snails in the experiment, they consumed all of them in a very short time. In natural habitats the snails would be afforded more refugia, so that they likely would be consumed by fish at a slower rate (Turner 1996). To simulate fish predation, we removed three snails from each snail tank at 3-d intervals and fed them to the fish in the fish treatments (36 snails per aquarium removed over the course of the experiment). Pilot experiments established that this should be an adequate maintenance ration for the fish and would also maximize the duration of the experiment. The treatments can be summarized as "algae-alone" [the control containing no animals], "snails-alone" [snails contained in the large side of the aquarium, with some removed at a constant rate and fed to the fish in the "fish-alone" treatment], "fishalone" [fish contained in the small side of the aquarium], and "fish + snail" treatment [snails contained in the large side of the aquarium, with some removed at a constant rate and fed to the fish on the small side of the same aquarium].

The initial animal densities used in our experiment ( $8 \mathrm{fish} / \mathrm{m}^{2}, 360$ snails $/ \mathrm{m}^{2}$ ) were higher than those found in nature. Centrarchid densities in regional ponds and reservoirs average 4 individuals $/ \mathrm{m}^{2}$, though densities range from 0 to 20 individuals $/ \mathrm{m}^{2}$ because the fish move in aggregations (Martin 1990). Natural snail densities range from 62 to 250 individuals $/ \mathrm{m}^{2}$ (Alexander and
Covich 1991, Harris 1992). Because we planned to remove snails throughout the experiment, we set the initial density to maintain realistic numbers over the majority of the experiment. It is not uncommon for "cage" experiments to contain higher than natural densities (due to constraints of cage size). As in any study where this is the case, we caution that the impacts of fish and snails in our study may be greater than those found in nature. However, the mechanisms of interactions we sought to elucidate should be common to both systems.

To minimize sample variability, artificial plants were used as substrata for the periphyton. The plants were made from bamboo skewers (the main stem) and black polypropylene ribbon cut into "leaves" $7.6 \mathrm{~cm}$ long $\left(7.0 \mathrm{~cm}^{2}\right)$; each "plant" supported 12 leaves. The ribbons were gently abraded with emery board to create a textured surface, allowing for a more diverse periphyton community than would have colonized smooth ribbon (Pringle 1990, Muntenau and Malay 1981). Five plants were attached to each tank by affixing five corks to the bottom of the larger section of aquarium with silicone sealer and positioning one bamboo skewer per cork. Materials for the artificial plants were preconditioned by soaking for $24 \mathrm{~h}$ in distilled water to leach any residual toxins (Burkholder and Wetzel 1989b). The artificial plants were constructed to mimic submersed Polygonum densiflorum, a common macrophyte in North Carolina littoral zones and the predominant macrophyte in Yates Mill Pond at the time of snail collection.

An algal inoculum was obtained by collecting macrophytes from Yates Mill Pond and Lake Johnson (both small meso/eutrophic impoundments in Wake County, North Carolina) and rinsing the associated periphyton into deionized water. This slurry was homogenized gently in a loosely fitting tissue grinder to create a homogenous mixture immediately before addition to the tanks (Burkholder and Wetzel 1989b). Each tank was inoculated with $50 \mathrm{~mL}$ of the periphyton slurry on 19 June, one day after the tanks had been filled with Raleigh city water treated to remove chloramines. Periphyton were allowed to colonize and grow for $2 \mathrm{wk}$ prior to the initiation of treatments. Snails were added on 29 June, and fish were added on 3 July. Once the treatments were imposed, the periphyton was exposed to grazing in the snail-alone treatment, nutrient recycling in the fish-alone treatment, and to both in the fish + snail treatment. In the algae-alone treatment periphyton was not exposed to either.

\section{Sampling procedure and processing}

Replicate water samples were collected for nutrient analyses from each aquarium at 10 -d intervals beginning 10 July. Samples were analyzed for total nitrogen, total phosphorus, and ammonium. Total phosphorus (TP) was measured following the acid persulfate digestion method of Prepas and Rigler (1982). Total ni- 
trogen (TN) was analyzed using the base persulfate digestion procedure of D'Elia and Steudler (1977). Ammonium was measured with the Solórzano method (Parsons et al. 1985) using modifications of Burkholder and Sheath (1985) for immediate preservation with phenol. Water samples collected on the day the tanks were filled (18 June) were used to assess initial nutrient levels $\left(\mathrm{TP}=32 \mu \mathrm{g} / \mathrm{L}, \mathrm{TN}=181 \mu \mathrm{g} / \mathrm{L}, \mathrm{NH}_{3}=30.5\right.$ $\mu \mathrm{g} / \mathrm{L})$. The $\mathrm{pH}$ was measured near the beginning and end of the experiment ( 8 July and 6 August) between 1130 and 1330, using a portable $\mathrm{pH}$ meter (Corning model PS-15).

Positions of snails were recorded on five dates (5, 11,23 , and 29 July and 6 August) to determine whether the presence of fish influenced snail behavior. We counted the number of snails in six locations: above the water line, on the upper surfaces of leaves, on the lower surfaces of leaves, on the glass (both bottom and sides of the aquaria), in the corners of the aquaria, and on the tank divider. On and after 23 July we found both snail eggs and recently hatched young. We did not include these small snails in the count to keep recruitment and location separate. At the end of the experiment all the tanks were emptied into a sieve. Snails were collected from the sieve as well as from the sides of the empty aquaria and remaining plants. We recorded the sizes (length of longest shell axis to nearest $0.05 \mathrm{~mm}$ ) and numbers of these snails, and the standard lengths (in millimeters) and masses (in grams) of the fish.

The periphyton was sampled at 10-d intervals beginning on 29 June (= one pre-treatment and four posttreatment samples). Following the methods of Burkholder and Wetzel $(1989 a, b)$, periphyton were collected by cutting eight leaves per tank and slowly floating them (still underwater) into a bottle filled with deionized water (custom-designed, long-handled forceps and scissors were used to sever leaves to minimize collection-related disturbance). Leaves were chosen so that a range of positions on the plants were sampled on every date. Within a sampling date, leaves from the same positions were taken from each tank. The leaf samples were preserved in acidic Lugol's solution (Vollenweider 1974). In the laboratory the periphyton cells were scraped from the eight leaves per aquarium using a rubber stopper and pooled into a single sample per aquarium. The samples were homogenized with a loosely fitting glass tissue grinder and a subsample of $150 \mathrm{~mL}$ was settled in a counting chamber for at least $20 \mathrm{~h}$ (Burkholder and Wetzel 1989b). Each chamber was examined at $450 \times$ with an Olympus inverted microscope using the Utermöhl method (Lund et al. 1958). Taxonomic identification, cell numbers, and biovolumes were determined for cells that were viable at sampling. Eukaryote algal cells were considered viable at sampling if the internal contents (e.g., chloroplasts and other organelles) were present; prokaryote blue-green algae were considered viable at sampling if the cells were pigmented (Burkholder and Wetzel
$1989 b)$. Identifications were made to genus according to Prescott $(1962,1978)$ and Whitford and Schumacher (1973). At least 400 viable cells were counted per sample. Cell counts were converted to biovolumes using standard geometric formulae for shapes that approximated the cell shape (Munawar et al. 1974, Burkholder and Wetzel 1989b). Biovolumes were estimated on a per-cell basis whether cells were solitary or filamentous. A minimum of 25 cells per taxon was used to determine mean dimensions when sufficient cell numbers were available. The surface area of the artificial leaves was measured (using a leaf area meter) and used to calculate number of algal cells per unit area of substrate.

Turbidity, which was likely related to phytoplankton density in the treatments, was scored on several dates (8, 11, and 23 July, and 6 August) using the following arbitrary scale: $0=$ clear (bottom of tank clearly visible), $1=$ visibility $<30 \mathrm{~cm}$ (artificial plant cork bottoms not visible), $2=$ visibility $<15 \mathrm{~cm}$ (highest leaf on artificial plants not visible).

\section{Statistical analysis}

Total phosphorus, total nitrogen, and ammonia for the factorial experiment were analyzed by repeatedmeasures ANOVA (for characteristics measured on the same experimental units on several occasions; Morrison 1976). The ANOVA model included the effects of block, fish, snails, and their interactions. The repeatedmeasures results were clear for TP and ammonia but less so for TN (a significant time effect and a nearly significant fish effect). To determine if the fish effect was significant at the end of the experiment, the TN data from each date were analyzed with a three-way ANOVA (block, fish, and snail). The $\mathrm{pH}$ was analyzed on both dates using a two-way ANOVA (block and treatment).

Snails were divided into two groups at the end of the experiment. Small snails $(<2 \mathrm{~mm})$ were smaller than those initially introduced and were assumed to be recruits produced by the adults in each treatment. Large snails $(>2 \mathrm{~mm}$ ) included primarily (but not exclusively) individuals that were introduced to the treatments. A $t$ test on the abundance of small snails tested for differences in snail reproduction (or survival of reproduced snails) among treatments. The analysis on the large snails tested for differences in mortality and growth. Snail position data was also analyzed using a $t$ test. The six categories were combined into two; snails on the divider, sides, and bottom of the aquaria and upper surfaces of the leaves were termed "visible" and snails in the corners of the aquaria, above the water line, and on the lower surfaces of the leaves were considered "hidden." We included only the first date in the analysis of snail position because on later dates visibility within tanks was confounded with treatment, although observed trends were similar. Change in fish body mass was analyzed using a two-way ANOVA. All 
ANOVAs were completed using the General Linear Models (GLM) procedure of the Statistical Analysis System (SAS 1987). Student's $t$ tests were computed by hand.

Before analysis, periphyton genera were grouped into the following categories; blue-green algae, green algae, cryptomonads, diatoms, dinoflagellates, red algae, and "total" (the combination of all groups). There were so few cryptomonads, dinoflagellates and reds that they were not examined as individual groups. Because both the algal taxa and the algal measurements (biovolume, cell number, and cell size) are correlated, we used multivariate analysis of variance (MANOVA) to detect overall effects of treatments on vectors of these responses. Prior to analysis, we used a natural $\log ($ datum +1$)$ transformation to normalize the data. The following set of responses were analyzed in one MANOVA: green algae cell number, diatom cell number, blue-green algae cell number, green algae cell size, diatom cell size, and blue-green algae cell size. Total periphyton and biovolume were not included because they are combinations of the responses already in the MANOVA. We then used univariate repeated-measures ANOVA to determine which specific responses accounted for the overall difference among treatments in the MANOVA. We did include biovolume and total periphyton in these analyses to determine the effect of fish and snails on the system as a whole. Turbidity data were analyzed using a two-way ANOVA for categorical data (SAS CATMOD). Periphyton data from the last date (8 August) were analyzed for fish and snail effects on algal growth form (percent adnate, percent colonial, etc.) using a three-way ANOVA. Community composition data from only the last date were included in the analysis because periphyton communities respond more slowly to manipulations of nutrients or grazers than phytoplankton communities and only after five or six weeks would treatment differences be likely to be reflected in different periphyton communities (J. Burkholder, personal communication). Community composition data (proportions) were arcsine-transformed before analysis.

\section{RESUlts}

\section{Fish}

All fish survived the experimental treatments. There were no differences among treatments in body-mass change of fish $\left(F_{2,9}=0.02, P=1.0\right)$. Fish lost an average of $2 \mathrm{~g}$ each (12\% of body mass) during the 6wk experiment.

\section{Snails}

Snails that were recovered from the tanks at the end of the experiment occupied a greater size range $(0.5-$ $10.5 \mathrm{~mm})$ than those that were first introduced (1.5$7.5 \mathrm{~mm}$ ), because of snail growth and reproduction during the experiment. Reproduction began during the
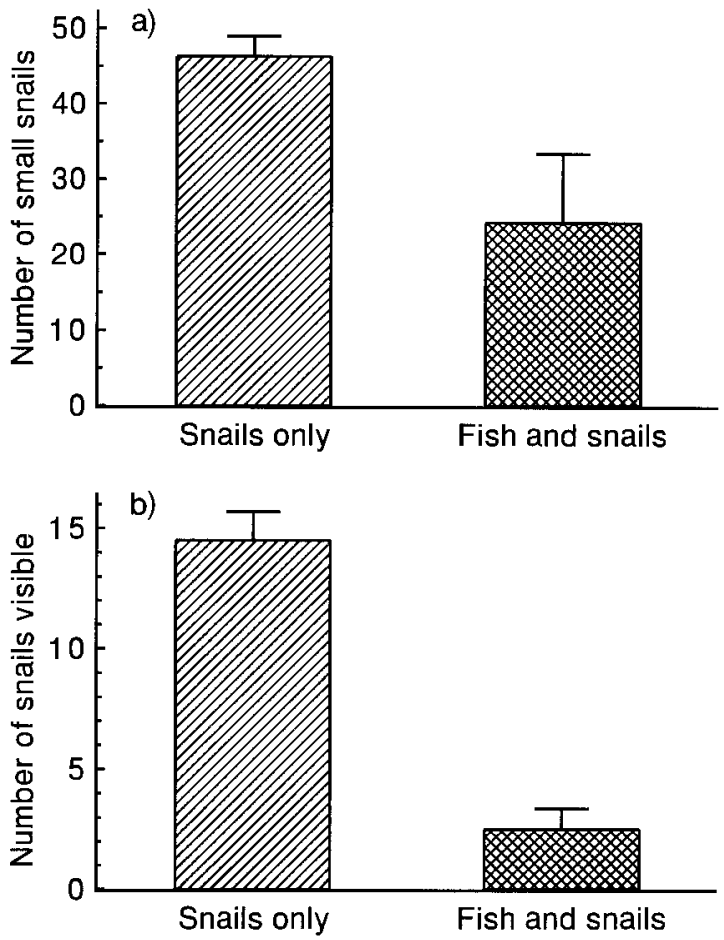

FIG. 1. Responses of snails to fish and fish-free environments (means and $1 \mathrm{SE}$ ). (a) Number of snails $<2 \mathrm{~mm}$ in length at the end of the experiment ( 8 August). (b) Number of snails "visible" (counted on upper surfaces of leaves, glass sides, or plastic divider) on 5 July.

third week of the experiment. The presence of fish reduced the number of small snails $(<2 \mathrm{~mm})$ apparently because of inhibited snail reproduction and/or increased snail mortality $\left(t_{\mathrm{df}=6}=2.81, P<0.05\right)$. Tanks with fish contained half the number of small snails found in tanks without fish (Fig. 1a). There were no significant differences in number of large snails among treatments $\left(t_{6}=1.27, P=0.2\right)$ but at the end of the experiment there were twice as many large snails in the snail-only treatments as in the fish+snail treatments. We did not anticipate snail reproduction and so expected to find nine large snails per aquarium at the end of the experiment regardless of the presence or absence of fish (45 initial snails - 36 removed snails). Instead there were an average 72.5 snails in the absence of fish and 35.5 snails in their presence.

Caged fish also influenced visibility of snails; in the absence of fish there were more snails foraging on the upper surfaces of the plant leaves and aquarium sides and dividers than with fish $\left(t_{6}=14.7, P<0.001\right.$; Fig. $1 b)$. In the presence of fish, snails stayed on the undersides of leaves (algal density was low to nonexistent on the lower surfaces due to light availability) and in the corners of the aquaria. If visibility indicates grazing activity, snails in the snail treatments were six times as active as in the fish + snail treatments. 

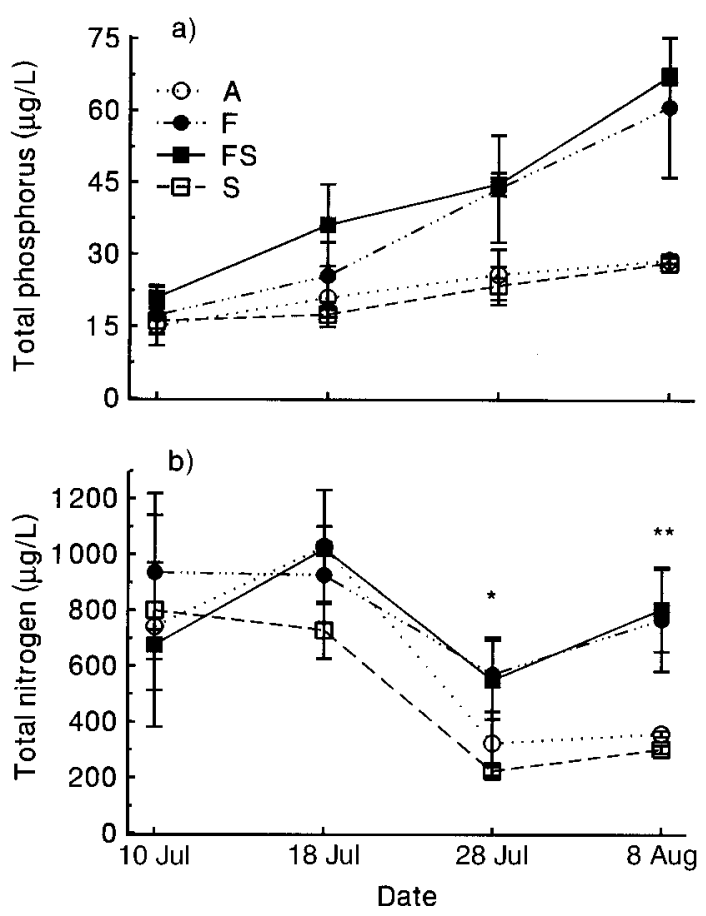

FIG. 2. Concentrations of (a) total phosphorus and (b) total nitrogen over time in the presence of algae alone (A) and with snails (S), fish (F), or fish and snails (FS). Data are means \pm 1 SE. First sample date is $11 \mathrm{~d}$ after initiation of treatments. Square symbols indicate treatments with snails; circles indicate treatments with no snails. Filled symbols indicate treatments with fish; open symbols indicate treatments with no fish. Asterisks denote significant fish effects according to date $\times$ date ANOVA $(* P<0.05$ and $* * * P<0.001)$.

\section{Nutrient concentrations}

Phosphorus concentrations (TP) were significantly higher in the fish treatments than in the nonfish treatments $\left(F_{1,8}=22.18, P<0.002\right)$ (Fig. 2a). By the end of the experiment, TP was $4 \times$ higher in the presence of fish than in their absence. Although not significant using the repeated-measures ANOVA, $\left(F_{1,8}=4.2, P\right.$ $<0.075)$, by the end of the experiment, mean nitrogen (TN) concentrations with fish were $2.5 \times$ higher than that of the mean without fish (Fig. 2b). TN levels were significantly higher in the presence of fish on 28 July $\left(F_{1,8}=8.33, P<0.02\right)$ and on 8 August $\left(F_{1,8}=27.31\right.$, $P<0.001)$. Ammonia concentrations did not differ among treatments or over time $\left(F_{1,8}=3.22, P=0.11\right)$. The differences in nutrient levels among treatments did not result in different $\mathrm{N}: \mathrm{P}$ ratios among treatments. The $\mathrm{N}$ :P ratio did, however, change over time, decreasing from an average of 55 to an average of 11 across treatments. There were no significant differences among treatments in $\mathrm{pH}\left(F_{3,12}=1.48, P<0.28\right.$ [10 July]; $F_{3,12}$ $=2.54, P<0.11$ [6 August]). The average $\mathrm{pH}$ was 8.5 on 10 July, and 9.3 on 6 August.

\section{Algae}

The MANOVA indicated significant date, fish, snail, and fish $\times$ snail interactions (Table 2 ).

Total periphyton.-There were twice as many periphyton cells in the absence of snails as with snails $\left(F_{1,8}=15.1, P<0.005\right.$; Fig. 3a). This effect did not translate into a significant negative effect of snails on biovolume because mean cell size increased in the presence of snails without fish (Figs. $4 \mathrm{a}$ and 5a). In the snail treatment average cell size was approximately twice that without snails $\left(F_{1,8}=9.66, P<0.015\right.$; Fig. $4 a)$. Interestingly, the snail effect on cell size was completely suppressed in the presence of fish, resulting in a significant fish effect on cell size $\left(F_{1,8}=10.58, P<\right.$ $0.012)$ and a significant fish $\times$ snail interaction $\left(F_{1,8}=\right.$ 9.79, $P<0.014)$. Mean algal cell size in the fish + snail treatment did not differ from mean algal cell size in treatments without snails.

Green algae.-Green algae (Chlorophyceae) made up $45-90 \%$ of the overall periphyton biovolume. Hence, results for this algal group were similar to those for total periphyton. The snail treatments contained sig-

TABLE 2. Summary of MANOVA on the response vector of the littoral-zone interaction study.

\begin{tabular}{lcrrc}
\hline \hline \multicolumn{1}{c}{ Source } & $\begin{array}{c}\text { Wilks } \\
\text { lambda }\end{array}$ & \multicolumn{1}{c}{$F$} & \multicolumn{1}{c}{ df } & $P$ \\
\hline Date & 0.21549328 & 3.4161 & 18,85 & 0.0001 \\
Block & 0.78618751 & 1.3598 & 6,30 & 0.2626 \\
Fish & 0.38089059 & 8.1271 & 6,30 & 0.0001 \\
Snail & 0.31725416 & 10.7602 & 6,30 & 0.0001 \\
Fish $\times$ Snail & 0.49538626 & 5.0931 & 6,30 & 0.0010 \\
Date $\times$ Block & 0.44826816 & 1.5551 & 18,85 & 0.0913 \\
Date $\times$ Fish & 0.47127557 & 1.4446 & 18,85 & 0.1322 \\
Date $\times$ Snail & 0.50508621 & 1.2950 & 18,85 & 0.2119 \\
Block $\times$ Fish & 0.71967387 & 1.9476 & 6,30 & 0.1053 \\
Block $\times$ Snail & 0.82661274 & 1.0488 & 6,30 & 0.4144 \\
Date $\times$ Block $\times$ Fish & 0.76565124 & 0.4694 & 18,85 & 0.9644 \\
Date $\times$ Block $\times$ Snail & 0.54871487 & 1.1207 & 18,85 & 0.3473 \\
Date $\times$ Fish $\times$ Snail & 0.63150394 & 0.8366 & 18,85 & 0.6532 \\
Block $\times$ Fish $\times$ Snail & 0.86890540 & 0.7544 & 6,30 & 0.6110 \\
\hline
\end{tabular}

Notes: Response vector includes means of green algae cell number, diatom cell number, bluegreen algae cell number, green algae cell size, diatom cell size, and blue-green algae cell size. 


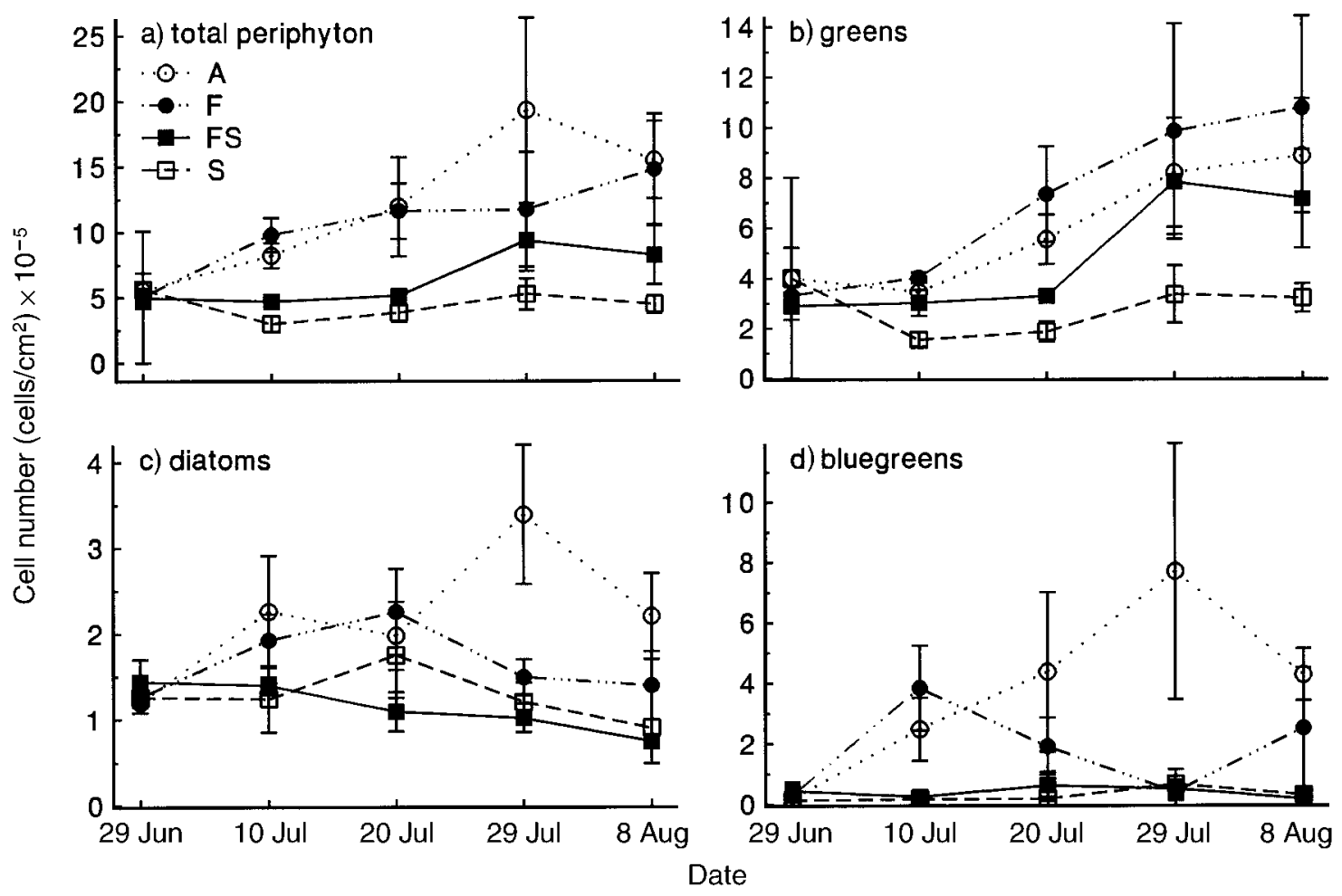

FIG. 3. Number of periphyton cells per sample over the course of the experiment (means \pm 1 SE). First sample date is prior to initiation of treatments; the rest are post-treatment. (a) Total number of periphyton cells, (b) green algal (Chlorophyta) cell number, (c) diatom (Chrysophyta) cell number, and (d) blue-green (Cyanophyta) cell number. Symbols are as in Fig. 2.

nificantly fewer cells than the algae and fish treatments $\left(F_{1,8}=5.22, P<0.051\right.$; Fig. 3b). There was no effect of treatment on green-algae biovolume because mean cell size was higher in the snail treatment $\left(F_{1,8}=6.13\right.$, $P<0.038$; Figs. 4b and 5b). Fish suppressed the effect of snails on cell size so that mean cell size in the fish + snail treatment was indistinguishable from that of the no-snail treatments (Fig. 4b). Thus, there was a significant effect of fish on green-algal cell size $\left(F_{1,8}\right.$ $=14.21, P<0.006)$ and a significant fish $\times$ snail interaction $\left(F_{1,8}=15.81, P<0.004\right)$.

Diatoms.-Diatoms (Bacillariophyceae) were the next most common algal division, comprising from 10 to $53 \%$ of the total periphyton biovolume among treatments. Again, snails significantly decreased diatom cell number $\left(F_{1,8}=20.78, P<0.002\right.$; Fig. $\left.3 \mathrm{c}\right)$, but unlike the influence of snails on total periphyton or green algae, this effect was translated into a significant negative effect on diatom biovolume $\left(F_{1,8}=9.87, P<\right.$ 0.014; Fig. 5c).

Diatom biovolume was also significantly reduced by fish $\left(F_{1,8}=9.34, P<0.016\right.$; Fig. $\left.5 \mathrm{c}\right)$. This was due to a nonsignificant trend for cell number to decrease in the presence of fish $\left(F_{1,8}=4.74, P<0.061\right.$; Fig. 3c) and a significant negative effect of fish on average diatom cell size $\left(F_{1,8}=7.18, P<0.028\right.$; Fig. $\left.4 \mathrm{c}\right)$. The negative effects of fish and snails on diatom biovolume were clearly evident when diatoms were divided into three size classes: small $\left(<350 \mathrm{~mm}^{3}\right)$, medium $(350-$ $\left.1000 \mathrm{~mm}^{3}\right)$, and large $\left(>1000 \mathrm{~mm}^{3}\right)$ (Fig. 6). There was consistently less diatom biovolume in the presence of snails than in their absence, indicating the negative effect of snails on cell number. The effect of fish on cell size was discerned by comparing the fish treatments (fish $[\mathrm{F}]$ and fish+snail [FS]; Fig. 6) to their "factorial controls" (algae [A] and snail [S]; Fig. 6). There were fewer large diatoms in the fish-only treatment than the algae treatment, and there were fewer large diatoms in the fish + snail treatment than in the snail-only treatment.

Blue-green algae.-Blue-green (Cyanophyceae) algal cell numbers were significantly lower in the presence of snails $\left(F_{1,8}=11.27, P<0.01\right.$; Fig. $\left.3 \mathrm{~d}\right)$. In the snail and fish + snail treatments there were virtually no blue-green algae. Mean cell size did not differ among treatments throughout the experiment $\left(F_{1,8}=0.47, P\right.$ $=0.5$; Fig. $4 \mathrm{~d}$ ) so the decrease in cell numbers resulted in a significant negative effect of snails on blue-green algal biovolume $\left(F_{1,8}=12.97, P<0.007\right.$; Fig. $\left.5 d\right)$.

Community composition and morphology.-Snails did not change the percentage of the community composed of adnate cells at the end of the experiment $\left(F_{1,11}\right.$ $=0.31, P=0.59)$, perhaps because the overall proportion of adnate cells was low $(<0.1$ in most aquaria). But snails did increase the percentage of the periphyton biovolume composed of gelatinous colonies (such as 


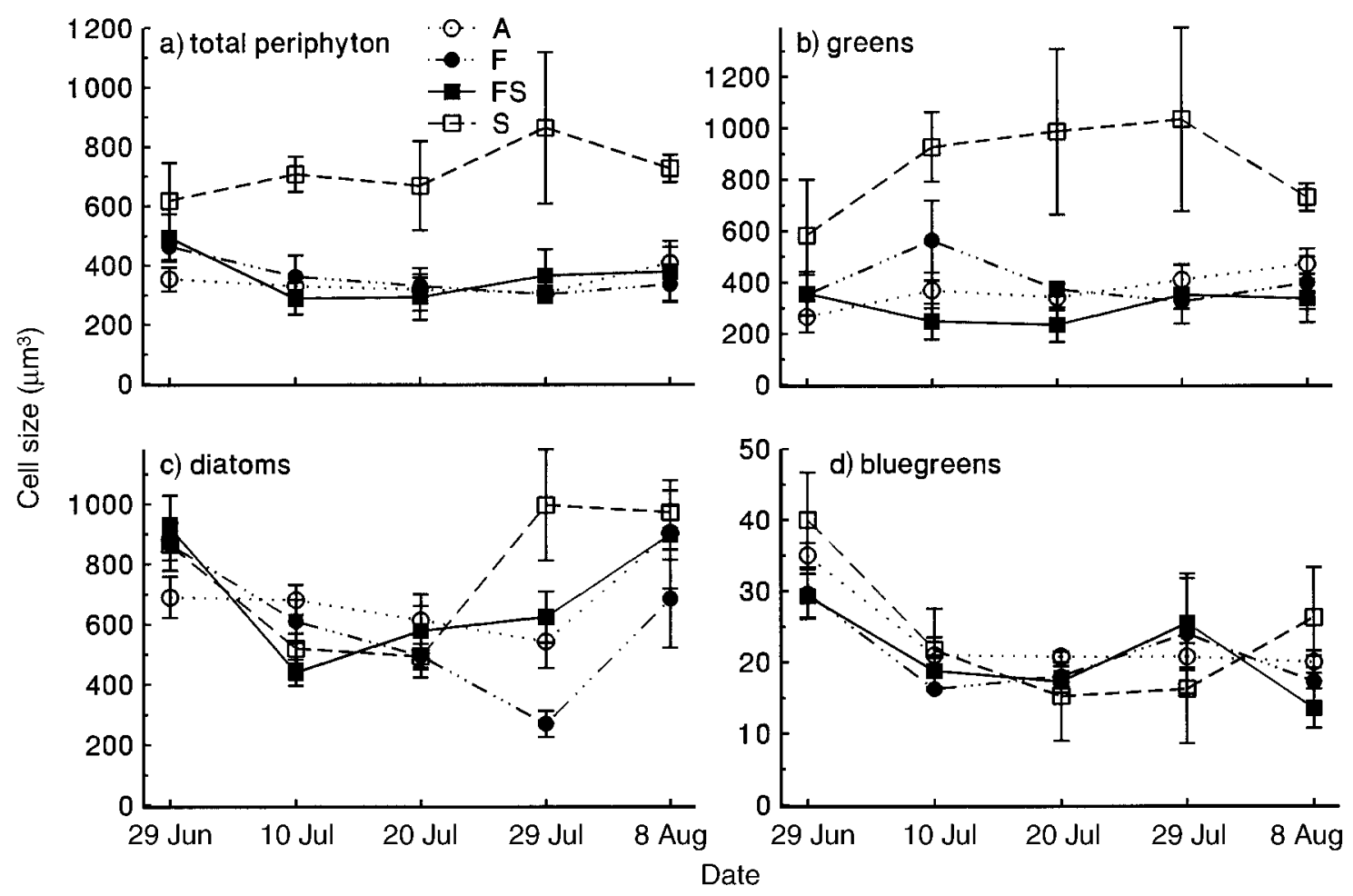

FIG. 4. Average periphyton cell size over the course of the experiment (means $\pm 1 \mathrm{SE}$ ). First sample date is prior to initiation of treatments; the rest are post-treatment; (a) average cell size of all periphyton, (b) average green algal (Chlorophyta) cell size, (c) average diatom (Chrysophyta) cell size, and (d) average blue-green (Cyanophyta) cell size.

Sphaerocystis, Coelastrum, and Gleocapsa $)\left(F_{1,11}=\right.$ 9.25, $P<0.011$; Fig. 7a) and decreased the percentage composed of filamentous forms (such as Oedogonium and Anabaena) $\left(F_{1,11}=13.38, P<0.0038\right.$; Fig. 7a). Although fish did not have a positive effect on filamentous forms, they did inhibit the negative effect of snails on filamentous algae, resulting in a significant fish $\times$ snail interaction $\left(F_{1,11}=5.54, P<0.038\right)$.

Green algae comprised a greater percentage of the community in all treatments as the experiment progressed. This primarily was due to the increase of the filamentous green alga Oedogonium inconspicuum. However, in the presence of fish, green algae comprised a greater percentage of the community than in no-fish treatments $\left(F_{1,11}=5.13, P<0.044\right.$; Fig. $\left.7 \mathrm{~b}\right)$. Snails decreased the proportion of the periphyton community made up of blue-green cells $\left(F_{1,11}=7.23, P<0.021\right.$; Fig. 7b).

Turbidity.-Fish significantly increased turbidity ( $P$ $<0.001$; Fig. 8). There were no sediments in the tank that could have been suspended by fish movement, and the water was green; hence, the decrease in visibility suggested that phytoplankton abundances were higher in the presence of fish.

\section{DISCUSSION}

We expected fish to affect periphyton indirectly through the consumption of snails (Hypothesis 1) and directly by regenerating nutrients (Hypothesis 2) (Table 1). As predicted, snails reduced the number of periphyton cells in all taxa by grazing (Hypothesis 1A). We also predicted that snail grazing would decrease biovolume (Hypothesis 1A). However, snails had no effect on total or green algal biovolume, although they did decrease diatom and blue-green algal biovolume. The lack of an effect on total and green algal biovolume apparently occurred because decreases in cell number and increases in cell size (green algae and total periphyton) with snails essentially canceled each other. We predicted that average cell size would decrease because larger cells are allegedly more vulnerable to snail grazing (Hypothesis 1B). Instead, snails increased total and green algal cell size, but had no effect on diatom and blue-green algal cell size. Apparently snails also have an upper limit in the size of cells that they can consume without difficulty. Cattaneo and Kalff (1986) found that in the presence of snails, extremely large cells $\left(10000 \mu^{3}\right)$ dominated the periphyton community. Thus, increased cell size in the presence of snails may result from selective grazing on intermediate-sized periphyton cells.

Although we predicted the proportion of adnate cells would increase in the presence of snails, there were no differences among treatments in this proportion (Hypothesis 1C). This is surprising, as it is one of the clearest reported effects of snails on periphyton com- 

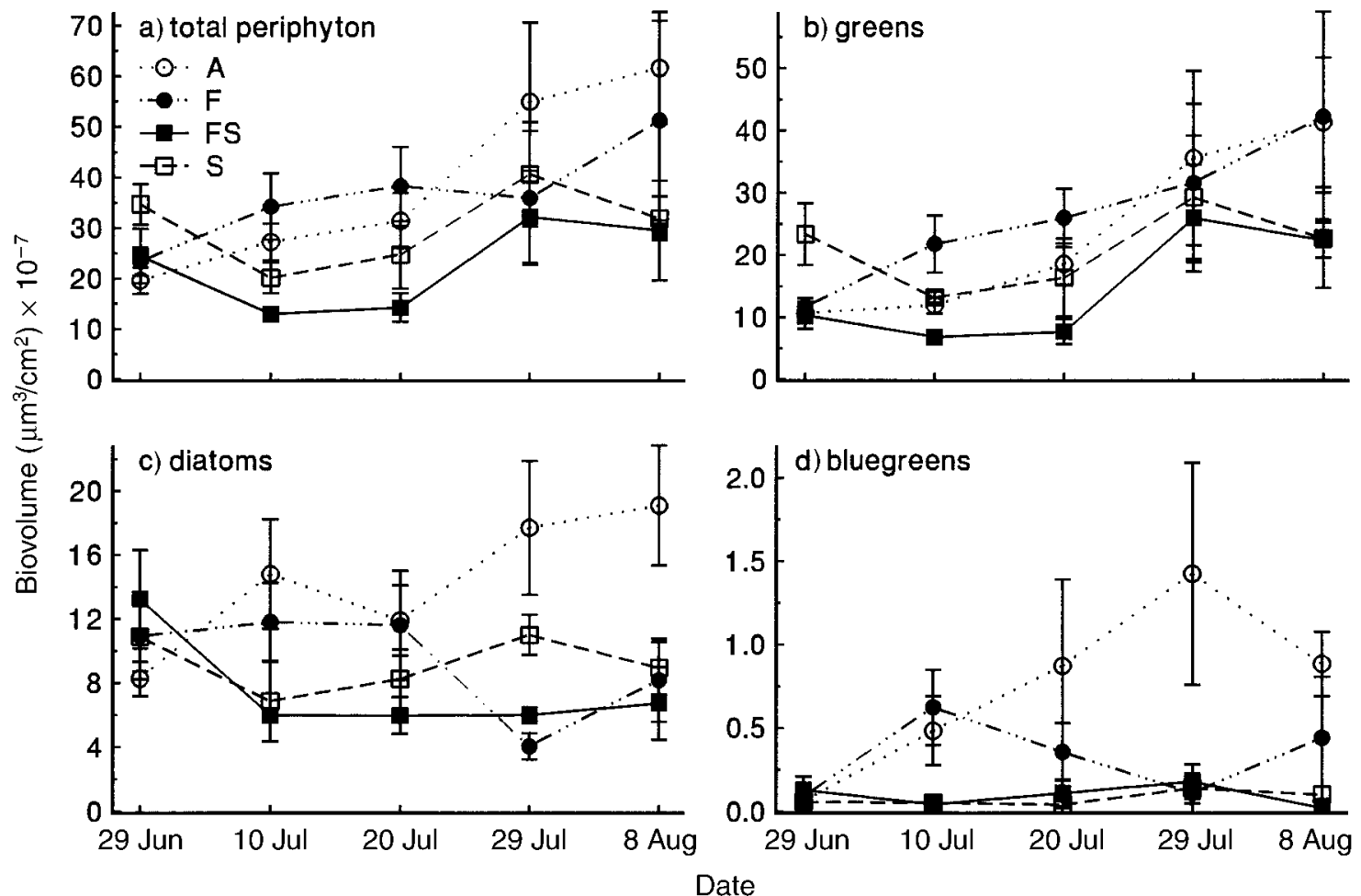

FIG. 5. Periphyton biovolume over the course of the experiment (means $\pm 1 \mathrm{SE}$ ). First sample date is prior to initiation of treatments; the rest are post-treatment. (a) Total periphyton biovolume, (b) green algal (Chlorophyta) biovolume, (c) diatom (Chrysophyta) biovolume, and (d) blue-green (Cyanophyta) biovolume.

munity composition (Brönmark 1989, McCormick and Stevenson 1991, Steinman et al. 1991). It may have been difficult to detect these effects in our experiment because adnate species were relatively rare in all our treatments.

In the presence of snails, we expected blue-green algae and gelatinous colonial green algae to increase relative to other forms because they are resistant to grazers (Hypothesis 1D). As predicted, snails increased the percentage of gelatinous colonies. In contrast to our predictions, the percentage of blue-green algae was

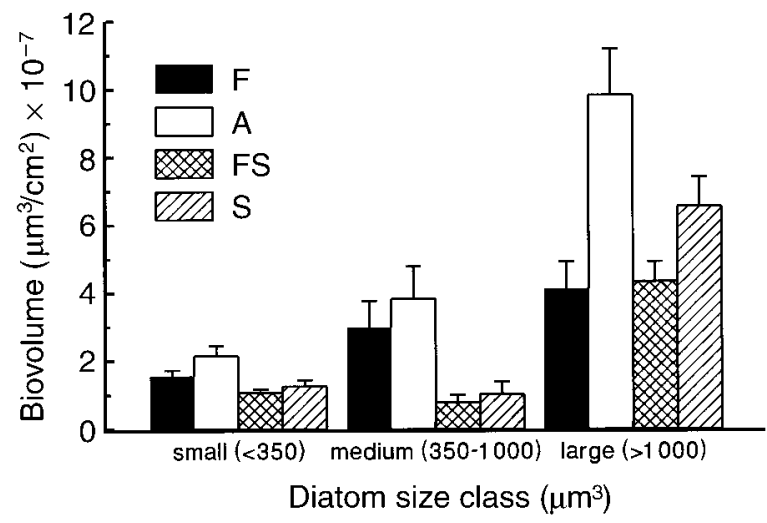

FIG. 6. Biovolume of three size classes of diatoms on 29 July. Bars are the means (and $1 \mathrm{SE}$ ) of four replicates. lower in the presence of snails than in their absence. Many blue-green algal species are toxic or unpalatable to snails and have been demonstrated to increase in the presence of herbivores (Cattaneo and Kalff 1986). Based on previous literature (Brönmark 1989, Porter 1977), it is unlikely that the snails were consuming blue-green algae preferentially. But a few studies suggest that snails select patches of edible algae, not edible cells, and are thereby less selective (Hunter 1980, Lowe and Hunter 1988). Blue-green filaments also may have been dislodged and inhibited from growing by the mechanical movement of snail feeding (Hunter 1980, Roos 1983, Lowe and Hunter 1988).

Hypothesis 1 did not include the possible effects of nutrient recycling on periphyton via the snails. The importance of snails as a potential nutrient source for the periphyton is unclear. Underwood (1991) found that nutrient recycling by snails occurs and has a positive effect on periphyton. But Cuker (1983) did not find any nutrient enrichment of periphyton due to snails. We did not examine this mechanism because Martin et al.'s (1992) data indicated that removing snails had a positive rather than negative effect on periphyton. But it could be important in some littoral systems.

As predicted, fish increased the concentrations of total phosphorus and total nitrogen in the water column (Hypothesis 2A), but this did not translate into increased algal biovolume or cell numbers (Hypothesis 

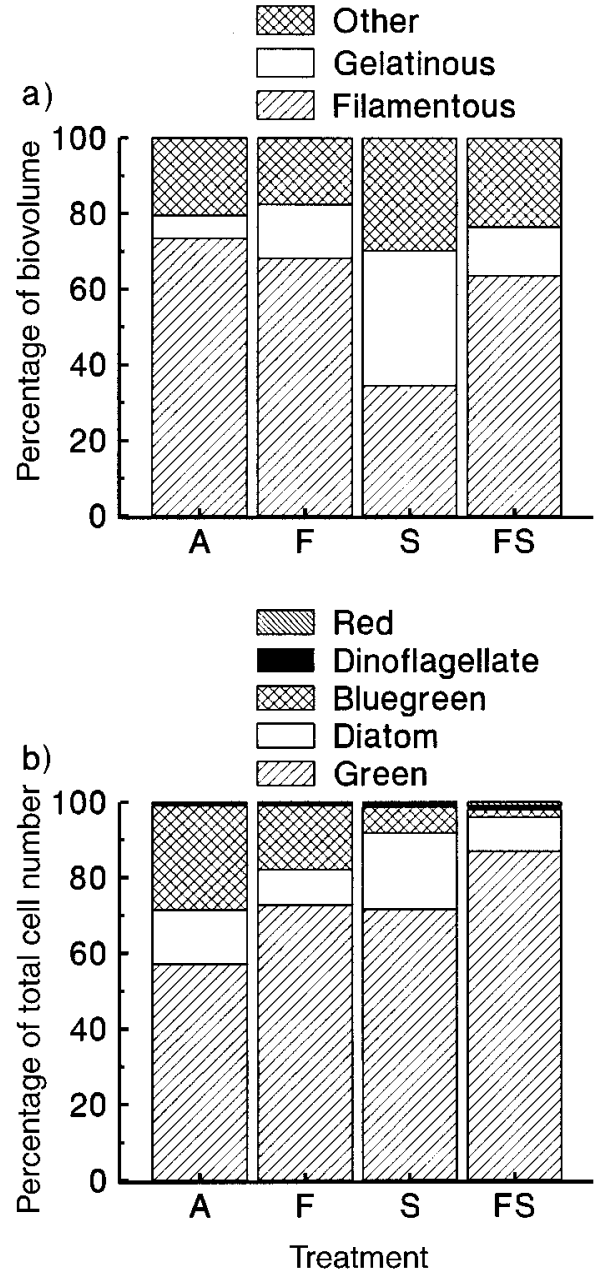

FIG. 7. (a) Percentage of periphyton biovolume comprising filaments, gelatinous colonies, and other growth forms on 8 August. (b) Taxonomic composition of periphyton by treatment. Green $=$ Chlorophyta, Diatom $=$ Chrysophyta, Bluegreen $=$ Cyanophyta, Dinoflagellate $=$ Pyrrhophyta, Red $=$ Rhodophyta.

2B). Also unexpectedly, fish decreased diatom biovolume. This resulted from a decrease in average diatom cell size in the presence of fish. Fish likewise had a negative effect on mean cell size of total periphyton and of green algae. Although we predicted that fish would decrease average cell size (Hypothesis 2C), our results were not via the expected mechanisms.

We predicted that diatoms would be smaller in the presence of fish because small cells have a competitive advantage when nutrients are patchy (Harris 1986, Steinman et al. 1992). The problem with ascribing this mechanism to the higher proportion of small diatoms in the presence of fish is that there were not more small cells with fish; there were fewer large cells. The reduced abundance of large diatoms may have been determined by competition for space with green algae. Fish significantly increased the proportion of the com- munity comprised of filamentous green algae (primarily Oedogonium) (predicted by Hypothesis 2D and 2E). Filaments have a competitive advantage over most algal cells because they can extend beyond the boundary layer and access nutrients unavailable to other cells (Stevenson et al. 1985, Riber and Wetzel 1987, Burkholder et al. 1990, Steinman et al. 1992). In addition, Oedogonium has extremely high rates of phosphorus assimilation, which can improve its competitive ability (Steinman et al. 1992).

As Oedogonium increased in the presence of fish in our experiment, it occupied a greater percentage of the space available for colonization. However, cells that could be successful under the Oedogonium matrix or live as epiphytes on the filaments may not have been limited by competition for space. Small diatoms were capable of both (Roos 1983), but large diatoms may not have been able to compete successfully for space and so declined in abundance. Fish, then, may have a direct effect on algal communities by increasing nutrients and shifting competitive dominance within the periphyton community.

Fish may also have affected mean total and mean green algal cell size via an effect on snail behaviors. When alone, snails increased algal cell size. By inhibiting snail grazing, fish completely suppressed this effect. In this experiment, about six times more snails were seen actively grazing on periphyton in the absence of fish. We cannot determine from this experiment whether snails actually altered their size selectivity patterns under predation risk or whether reductions in grazing activity alone could account for this shift. McCormick (1990) found that sunfish reduced snail grazing without increasing snail mortality. In another study, snails spent a greater amount of time out of the water in the presence of predatory crayfish, which decreased the amount of time they spent grazing on periphyton (Alexander and Covich 1991). Turner (1996) found that snails exposed to water that had been in contact with crushed conspecifics increased their refuge use twofold over controls.

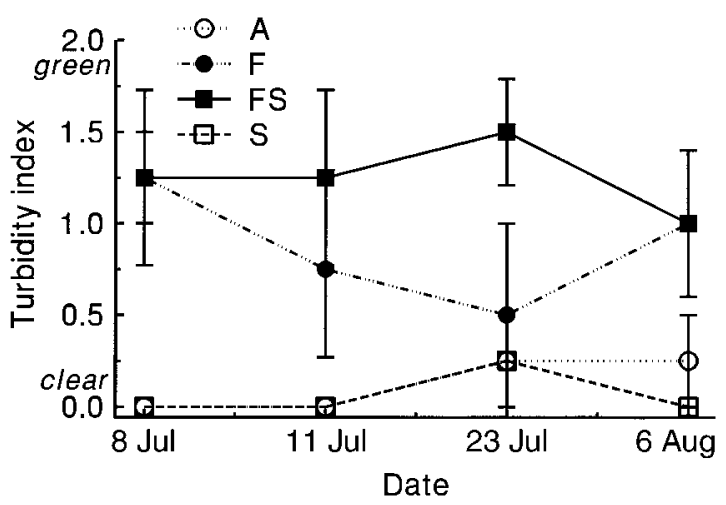

FIG. 8. Turbidity over the course of the experiment (means $\pm 1 \mathrm{SE}$ ). Higher values of this index indicate lower transparency. 
In our experiment, redear sunfish further reduced cumulative snail grazing by either inhibiting snail reproduction or increasing snail mortality or both. Overall, the snail-alone treatments had about twice as many snails (both large and small) at the end of the experiment as did snail populations with fish, despite identical snail removal protocols. Predation by fish on new recruits small enough to cross the plastic barrier is unlikely to be the cause of this difference in abundance. Snails were rarely observed on the divider when fish were present though they were often seen on the "snail side" of the divider when fish were absent. Only two snails were ever found to have crossed the divider in any treatment. Snail eggs and new recruits were not seen until 23 July indicating that differences in snail numbers or size structure could only account for differences in algal composition or size during the last 2 wk of the experiment.

Other studies have found similar shifts in snail life history traits in the presence of predators. In the presence of a crayfish cue (i.e., no actual contact between snails and crayfish), Physella virgata exhibited rapid growth rates and little reproduction until they reached $10 \mathrm{~mm}$ (Crowl and Covich 1990). In the absence of the crayfish cue, snails began to reproduce at $4 \mathrm{~mm}$. The presence of the central mudminnow (Umbra limi) reduced the number of egg masses and the abundance of juvenile snails of Lymnaea elodes (Brown and DeVries 1985). Alternatively, reproduction could have been similar across treatments but mortality could have been higher in the presence of fish even without direct contact. For instance, reduced grazing rates could decrease survival. McCollum and Van Buskirk (1996) found that dragonflies decreased tadpole survival even though the dragonflies were caged and had no direct contact with the tadpoles. Predators can, therefore, have important indirect effects on periphyton abundance and size structure by producing waterborne cues that influence snail life history and behavior.

The differences in turbidity among fish and no-fish treatments suggest that there were more phytoplankton in the tanks with fish. Periphyton and phytoplankton compete for the same resources (light and nutrients) within the littoral zone, so proliferation of one often has negative repercussions on the other (Kuhn et al. 1981, Roos 1983, Hansson 1988, 1990). Although we do not have direct evidence that phytoplankton increased in our experiment, the change in turbidity suggests it as a reasonable possibility. It is conceivable that fish increased the concentration of available nutrients causing an increase in the phytoplankton population. This in turn decreased the light available to the periphyton and resulted in the nonresponse of periphyton biovolume to fish nutrients. Future studies of periphyton should include observations of phytoplankton to determine the importance of their interactions.

Rather than maintain their initial body mass, the fish in our experiment lost $\sim 12 \%$ of their mass. But this was not an unrealistic scenario; a mass loss of $\geq 15 \%$ is not uncommon for food-limited fish at summer temperatures (Swingle and Smith 1940, Swingle 1951, Beamish et al. 1975, Brett 1979, Elliott 1981, Rice et al. 1983). Over the long term, fish that lose body mass may be a net source of nutrients whereas fish that gain mass may be a sink for nutrients. However, over the short term, starved fish release fewer nutrients than fed fish (Rychly and Marina 1977, Mather et al. 1995). Thus the mass loss in our experimental fish probably decreased our ability to see a strong effect of fishrecycled nutrients on periphyton.

In addition to increasing the amount of nitrogen and phosphorus in the water column, fish can alter the ratio between the two. The N:P ratio can have important effects on algal community composition (Rhee 1978, Tilman 1982, Smith 1983). We monitored the N:P ratio for this reason but found that the $\mathrm{N}: \mathrm{P}$ ratio did not differ among treatments. N:P ratios did change over time (from 55 to 11 ) suggesting that the algae were becoming increasingly $\mathrm{N}$ limited. We would expect a change in N:P to cause a shift toward blue-green dominance in the community (Smith 1983), a result that we did not see in any treatment. Changes in N:P ratio appeared to have little effect in our experiment.

Because our experiment required manipulating the presence and absence of fish and snails, we were also manipulating total nutrient pools and whether nutrients were available or sequestered. The initial nutrient pool in treatments containing fish or snails was higher than in treatments with algae alone. Some studies on algae assume that biovolume is determined primarily, if not completely, by the total amount of nutrients in the system (the total nutrient pool or set point [Power 1992]). This perspective usually holds true over the long term but over the short term the nutrients sequestered in animal bodies are not available to the algae (Vanni 1996). The animals can be sinks rather than sources of nutrients, particularly when they are growing (Mather et al. 1995, Vanni 1996). Even on large scales such as in whole lake manipulations, changing fish and herbivore biomass does relatively little to the sestonic nutrients (Carpenter and Kitchell 1993a, Kitchell and Carpenter 1993). Since we were interested in nutrients available to the periphyton over the short term (days to weeks), we did not expect the difference in animal biomass among our treatments to be an important influence on the periphyton community. However, we examined the alternative hypothesis that change in total nutrient pools among treatments explains our results.

If manipulating animal biomass, and therefore the total nutrient pool of our experimental systems, had any effect on the periphyton biovolume, we would predict that biovolume would be greatest in the fish + snail treatment. Periphyton biovolume in the fish treatment should be less than in the fish + snail treatment but greater than in either the algae or snail treatment. The expected ranking between the algae and snail treatment 
is debatable because we initially "added" nutrients relative to the algae treatment by adding snails, but we were "removing" nutrients throughout the experiment by artificially imposing predation on the snails and removing them. Thus, based on total nutrient pools or set points, we would expect the final treatment biovolumes of periphyton to be ranked FS $>\mathrm{F}>$ (A ? $\mathrm{S})$. Our experimental results rank as $\mathrm{A}>\mathrm{F}>\mathrm{S}=\mathrm{FS}$. The fish + snail treatment, which had the most nutrients added as animal biomass, had the lowest periphyton biovolume. The algae treatment had the highest biovolume instead of lowest or next to lowest. These results are opposite the total nutrient pool predictions. Thus, although we changed the total amount of nutrients in the system by manipulating presence and absence of animals, this had little effect on the periphyton biomass. Fish and snails had important effects on periphyton via different mechanisms.

In summary, some of the results support the predictions in Table 1 while others were unexpected and therefore increased our understanding of the system. As expected, periphyton cell numbers decreased in the presence of snails but unexpectedly periphyton biovolume remained unchanged. Snail grazing changed average cell size but in the opposite direction from the prediction. Grazing also increased the proportion of grazer-resistant colonial green algae but surprisingly did not also increase the proportion of blue-green algae. This suggests that snail grazing strongly influenced, but did not completely control, periphyton abundance and size structure. As anticipated, nutrient concentrations were higher in the presence of fish but we did not see an increase in algal biovolume as a result of the higher nutrients. Mean periphyton cell size decreased, though probably for different reasons than we predicted. Large, filamentous green algae made up a greater percentage of the community in fish treatments but the expected concomitant increase in blue-green algae did not occur. Thus, fish can have important direct effects on algae, though they may be more subtle (i.e., seen in changes in community composition rather than biovolume) than their indirect effects.

Our initial hypotheses did not anticipate fish effects on snail behavior, reproduction, or survival. Despite identical removals of snails in snail and fish + snail treatments, snail grazing activity (as gauged by number of snails observed foraging) was reduced nearly six times in the presence of fish; similarly, fish suppressed snail reproduction and/or increased snail mortality by nearly a factor of two. This led to a significant fish $\times$ snail interaction (for total and green algal cell size, and biovolume of filamentous algae) where the negative effects of snails were suppressed in the presence of the caged fish. Thus, fish have important effects on snail life history and behavior independent of predation, which in turn can influence periphyton.

Strong (1992) argues that trophic cascades are rare and only occur in simple food webs with only a single or a few key herbivore species and only a single or a few key carnivores. The pelagic cascade supports this theory in that cascades seem to be apparent primarily when large Daphnia species are present (Kerfoot 1987, Carpenter and Kitchell 1993b). Daphnia are strongly influenced by planktivores (Hrbacek 1962, Brooks and Dodson 1965, Galbraith 1967, Mills et al. 1987) and can behaviorally avoid predation via vertical migration. Daphnia have high grazing rates and are generalist feeders, allowing them to have a strong influence on phytoplankton populations.

Many characteristics of Physella in the littoral cascade are similar to characteristics of Daphnia in the pelagic cascade. There is increasing evidence that snail distributions can be controlled by predation (Brönmark et al. 1992, Martin et al. 1992). In addition, our results suggest that the direct effect of predation on snail abundance may be augmented by shifts in snail behavior and life history traits. All of these mechanisms suggest that the strong link between predators and prey predicted for trophic cascades exists between molluscivores and snails.

Our study shows that fish can have effects on periphyton through multiple pathways. Previous research (Brönmark et al. 1992, Martin et al. 1992, Lodge et al. 1994) suggests that fish and crayfish have a positive indirect effect on algae by removing snail grazers. Our data support this while showing that fish enhance this effect by inhibiting snail reproduction and by suppressing grazing activity. In addition, our data suggest that fish can have an important direct effect on algae, through the resupply of nutrients and potentially by altering competitive outcomes among taxa and growth forms (cf. Rosemond 1996). Our findings also document that more than just biomass measures are needed to quantify the response of periphyton communities to both resource-based and predation-based forces. By measuring algal cell number, cell size, community composition, and growth form, we were able to more clearly separate the complex effects of fish on nutrients and grazers and ultimately on the littoral periphyton.

\section{ACKNOWLEDGMENTS}

T. Martin's experimental work and advice provided inspiration for this project. We thank J. Burkholder, who provided lab space, equipment, taxonomic training, and valuable advice. We thank D. Schael, and P. Gama for assistance in the field, L. Taggett, G. Coleman, and H. Glasgow for help in the lab, and D. Hare, S. Peacor, E. Werner, C. Brönmark, M. Vanni, G. Mittelbach, and an anonymous reviewer for comments on an earlier version of the manuscript. Financial support was provided by a NSF Graduate Fellowship (EWM) and by NSF BSR-8709108 (LBC). S. A. McCollum was supported by NSF DEB 9408397 (to S. A. McCollum, E. E. Werner, and J. Van Buskirk) during manuscript preparation.

\section{Literature Cited}

Alexander, J. E., Jr., and A. P. Covich. 1991. Predator avoidance by the freshwater snail Physella virgata in response to the crayfish Procambarus simulans. Oecologia (Berlin) 87:435-442.

Beamish, F. W. H., A. J. Nimi, and P. H. K. P. Lett. 1975. 
Bioenergetics of teleost fishes: environmental influences. Pages 187-209 in L. Bolis, H. P. Maddrell, and K. SchmidtNielsen, editors. Comparative physiology-functional aspects of structured materials. North-Holland Publishers, Amsterdam, The Netherlands.

Brabrand, A., B. A. Faafeng, and J. P. M. Nilssen. 1990. Relative importance of phosphorus supply to phytoplankton production: fish excretion versus external loading. Canadian Journal of Fisheries and Aquatic Science 47:364372.

Brett, J. R. 1979. Environmental factors and growth. Pages 599-675 in W. S. Hoar, D. J. Randall, and J. R. Brett, editors. Fish physiology. Volume three. Bioenergetics and growth. Academic Press, New York, New York, USA.

Brönmark, C. 1989. Interactions between epiphytes, macrophytes and freshwater snails: a review. Journal of Molluscan Studies 55:299-311.

- 1994. Effects of tench and perch on interactions in a freshwater, benthic food chain. Ecology 75:1818-1824.

Brönmark, C., S. P. Klosiewski, and R. A. Stein. 1992. Indirect effects of predation in a freshwater, benthic food chain. Ecology 73:1662-1674.

Brooks, J. L., and S. I. Dodson. 1965. Predation, body size, and the composition of the plankton. Science 150:28-35.

Brown, K. M., and D. R. DeVries. 1985. Predation and the distribution and abundance of a pulmonate pond snail. Oecologia (Berlin) 66:93-99.

Burkholder, J. M., and R. G. Sheath. 1985. Characteristics of softwater streams in Rhode Island. I. A. Comparative analysis of physical and chemical variables. Hydrobiologia 120:97-108.

Burkholder, J. M., and R. G. Wetzel. 1989a. Epiphytic microalgae on natural substrata in a hardwater lake: seasona dynamics of community structure, biomass and ATP content. Archiv für Hydrobiologie, Supplementband 83:1-56

Burkholder, J. M., and R. G. Wetzel. 1989b. Microbial colonization on natural and artificial macrophytes in a phosphorus-limited, hardwater lake. Journal of Phycology 25 $55-65$.

Burkholder, J. M., R. G. Wetzel, and K. K. Klomparens. 1990. Direct comparison of phosphate uptake by adnate and loosely attached microalgae within an intact biofilm matrix. Applied and Environmental Microbiology 56:2882-2890.

Carney, H., P. Richarson, C. Goldman, and R. Richards. 1988 Seasonal phytoplankton demographic process and experiments on interspecific competition. Ecology 69:664-678.

Carpenter, S. R., and J. F. Kitchell. 1992. Trophic cascade and biomanipulation: interface of research and management-A reply to DeMelo et al. Limnology and Oceanography 37:208-213.

Carpenter, S. R., and J. F. Kitchell. 1993a. Experimental lakes, manipulations and measurements. Pages 15-25 in S. R. Carpenter and J. F. Kitchell, editors. The trophic cascade in lakes. Cambridge University Press, Cambridge, UK

Carpenter, S. R., and J. F. Kitchell. 1993b. The Trophic Cascade in Lakes. Cambridge University Press, Cambridge, UK.

Carpenter, S. R., J. F. Kitchell, and J. R. Hodgson. 1985 Cascading trophic interactions and lake productivity. BioScience 35:634-639.

Carpenter, S. R., J. F. Kitchell, J. R. Hodgson, P. A. Cochran, J. J. Elser, M. M. Elser, D. M. Lodge, D. Kretchmer, X. He, and C. N. vonEnde. 1987. Regulation of lake primary productivity by food web structure. Ecology 68:18631876.

Cattaneo, A., and J. Kalff. 1986. The effect of grazer size manipulation on periphyton communities. Oecologia (Berlin) 69:612-617.

Crowder, L. B., R. W. Drenner, W. C. Kerfoot, D. J. McQueen, E. L. Mills, U. Sommer, C. N. Spencer, and M. J. Vanni.
1988. Food web interactions in lakes. Pages 141-160 in S. R. Carpenter, editor. Complex interactions in lake communities. Springer-Verlag, Berlin, Germany.

Crowl, T. A., and A. P. Covich. 1990. Predator-induced lifehistory shifts in a freshwater snail. Science 247:949-951.

Cuker, B. E. 1983. Grazing and nutrient interaction in controlling the activity and composition of the epilithic algal community of an arctic lake. Limnology and Oceanography 28:33-141.

D'Elia, C. F., and P. A. Steudler. 1977. Determination of total nitrogen in aqueous samples using persulfate digestion. Limnology and Oceanography 22:760-764.

DeMelo, R., R. France, and D. J. McQueen. 1992. Biomanipulation-Hit or myth? Limnology and Oceanography 37:192-207.

Dillon, P., and F. Rigler. 1974. The phosphorus-chlorophyll relationship in lakes. Limnology and Oceanography 19: 767-773.

Drenner, R. W., S. T. Threlkeld, and M. D. McCracken. 1986. Experimental analysis of the direct and indirect effects of an omnivorous filter-feeding clupeid on plankton community structure. Canadian Journal of Fisheries and Aquatic Sciences 43:1935-1945.

Elliott, J. M. 1981. Some aspects of thermal stress on freshwater teleosts. Pages 209-246 in Stress and fish. A. D. Pickering, editor. Academic Press, London, UK.

Elwood, J. W., J. D. Newbold, A. F. Trimble, and R. W. Stark. 1981. The limiting role of phosphorus in a woodland stream ecosystem: effects of P enrichment on leaf decomposition and primary producers. Ecology 62:146-158.

Galbraith, M. G. 1967. Size-selective predation of Daphnia by rainbow trout and yellow perch. Transactions of the American Fisheries Society 96:1-10.

Hambright, K. D., R. J. Trebatoski, R. Drenner, and D. Kettle. 1986. Experimental study of the impacts of bluegill (Lepomis macrochirus) and largemouth bass (Micropterus salmoides) on pond community structure. Canadian Journal of Fisheries and Aquatic Sciences 43:1171-1176.

Hansson, L. 1988. Effects of competitive interactions on the biomass and development of planktonic and periphytic algae in lakes. Limnology and Oceanography 33:121-128. 1990. Quantifying the impact of periphytic algae on nutrient availability for phytoplankton. Freshwater Biology 24:265-273.

. 1992. The role of food chain composition and nutrient availability in shaping algal biomass development. Ecology 73:241-247.

Hansson, L., L. Johansson, and L. Persson. 1987. Effects of fish grazing on nutrient release and succession of primary producers. Limnology and Oceanography 32:723-729.

Harris, G. P. 1986. Phytoplankton ecology: structure, function and fluctuation. Chapman and Hall, London, UK.

Harris, P. M. 1992. Community-wide consequences of single-species perturbations in experimental aquatic systems. Dissertation. Department of Zoology, Duke University, Durham, North Carolina, USA.

Hecky, R. E., and R. H. Hesslein. 1995. Contribution of benthic algae to lake food webs as revealed by stable isotope analysis. Journal of the North American Benthological Society 14:631-653.

Hrbacek, J. 1962. Species composition and the amount of zooplankton in relation to fish stock. Rozpravy Ceskoslovenske Akademie Ved. Rada Matematickych a Priodnich Ved 72:1-116.

Hunter, R. D. 1980. Effects of grazing on the quantity and quality of freshwater aufwuchs. Hydrobiologia 69:251259.

Hunter, M. D., and P. W. Price. 1992. Playing chutes and ladders: heterogeneity and the relative roles of bottom-up 
and top-down forces in natural communities. Ecology 73: 724-732.

Kerfoot, W. C. 1987. Cascading effects and indirect pathways. Pages 57-70 in C. Kerfoot and A. Sih, editors. Predation. University Press of New England, Hanover, New Hampshire, USA.

Kitchell, J. F., and S. R. Carpenter. 1993. Synthesis and new directions. Pages 332-350 in S. R. Carpenter and J. F. Kitchell, editors. Trophic Cascade in Lakes. Cambridge University Press, Cambridge, UK.

Kraft, C. E. 1992. Estimates of phosphorus and nitrogen cycling by fish using a bioenergetics approach. Canadian Journal of Fisheries and Aquatic Science 49:2596-2604.

Kuhn, D. L., J. L. Plafkin, J. Cairns Jr., and R. Lowe. 1981 Qualitative characterization of aquatic environments using diatom life-form strategies. Transactions of the American Microscope Society 100:165-182.

Lamberti, G. A., and V. H. Resh. 1983. Stream periphyton and insect herbivores: an experimental study of grazing by a caddisfly population. Ecology 64:1124-1135.

Leibold, M. A. 1989. Resource edibility and the effects of predators and productivity on the outcome of trophic interactions. American Naturalist 134:922-949.

Littler, M. M. 1980. Morphological form and photosynthetic performances of marine macroalgae: tests of a functional/ form hypothesis. Botanica Marina 22:161-165.

Lodge, D. M., J. W. Barko, D. Strayer, J. M. Melack, G. G. Mittelbach, R. W. Howarth, B. Menge, and J. E. Titus. 1988. Spatial heterogeneity and habitat interactions in lake communities. Pages 181-208 in S. R. Carpenter, editor. Complex interactions in lake communities. Springer-Verlag, New York, New York, USA.

Lodge, D. M., M. W. Kershner, and J. Aloi. 1994. Effects of an omnivorous crayfish (Orconectes rusticus) on a freshwater littoral food web. Ecology 75:1265-1281.

Lowe, R. L., and R. D. Hunter. 1988. Effect of grazing by Physa integra on periphyton community structure. Journal of the North American Benthological Society 7:29-36.

Lund, J. W. G., C. Kipling, and E. D. LeCren. 1958. The inverted microscope method of estimating algal numbers and the statistical basis of estimations by counting. Hydrobiologia 11:142-170.

Martin, T. H. 1990. Direct and indirect effects of fish predation on the fresh-water littoral benthos. Dissertation, Department of Zoology, North Carolina State University, Raleigh, North Carolina, USA.

Martin, T. H., L. B. Crowder, C. F. Dumas, and J. M. Burkholder. 1992. Indirect effects of fish on macrophytes in Bays Mountain Lake: evidence for a littoral trophic cascade. Oecologia (Berlin) 89:476-481.

Mather, M. E., M. J. Vanni, T. E. Wissing, S. A. Davis, and M. H. Schaus. 1995. Regeneration of nitrogen and phosphorus by bluegill and gizzard shad: effect of feeding history. Canadian Journal of Fisheries and Aquatic Sciences 52:2327-2339.

McCollum, S. A., and J. Van Buskirk. 1996. Costs and benefits of a predator-induced polyphenism in the gray treefrog, Hyla chroysoscelis. Evolution 50:583-593.

McCormick, P. V. 1990. Direct and indirect effects of consumers on benthic algae in isolated pools of an ephemeral stream. Canadian Journal of Fisheries and Aquatic Science 47:2057-2065.

McCormick, P. V., and R. J. Stevenson 1989. Effects of snail grazing on benthic algal community structure in different nutrient environments. Journal of North American Benthological Society 8:162-172.

McCormick, P. V., and R. J. Stevenson. 1991. Grazer control of nutrient availability in the periphyton. Oecologia (Berlin) 86:287-291

McQueen, D. J., J. R. Post, and E. L. Mills. 1986. Trophic relationships in freshwater pelagic ecosystems. Canadian Journal of Fisheries and Aquatic Science 43:1571-1581.

Mills, E. L., J. L. Forney, and K. J. Wagner. 1987. Cascading effect of predation on the Oneida Lake food chain. Pages 118-131 in C. Kerfoot and A. Sih, editors. Predation. University Press of New England, Hanover, New Hampshire, USA.

Morrison, D. F. 1976. Multivariate statistical methods. McGraw Hill, New York, New York, USA.

Mulholland, P. J., A. D. Steinman, A. V. Palumbo, J. W. Elwood, and D. B. Kirschtel. 1991. Role of nutrient cycling and herbivory in regulating periphyton communities in laboratory streams. Ecology 72:966-982.

Munawar, M., P. Stadelmann, and I. F. Munawar. 1974. Phytoplankton biomass, species composition and primary production at a nearshore and midlake station of Lake Ontario during IFYGL. Pages 629-652 in International Association of Great Lakes Research, Proceedings of the 17th Conference on Great Lakes Research.

Mundie, J. H., K. S. Simpson, and C. J. Perrin. 1991. Responses of stream periphyton and benthic insects to increases in dissolved inorganic phosphorus in a mesocosm. Canadian Journal of Fisheries and Aquatic Science 48: 2061-2072.

Muntenau, N., and E. J. Malay. 1981. The effect of current on the distribution of diatoms settling on submerged glass slides. Hydrobiologia 78:278-282.

Northcote T. G. 1988. Fish in the structure and function of freshwater ecosystems: a "top-down" view. Canadian Journal of Fisheries and Aquatic Sciences 45:361-379.

Paine, R. T. 1980. Food webs: linkage, interaction strength, and community infrastructure. Journal of Animal Ecology 49:667-685.

Parsons, T. R., Y. Maita, and C. M. Lalli. 1985. A manual of chemical and biological methods for seawater analysis. Pergamon, New York, New York, USA.

Peters, R. H. 1986. The role of prediction in limnology. Limnology and Oceanography 31:1143-1159.

Porter, K. G. 1977. The plant-animal interface in freshwater ecosystems. American Scientist 65:159-170.

Power, M. E. 1992. Top-down and bottom-up forces in food webs: Do plants have primacy? Ecology 73:733-746.

Prepas, E. E., and F. A. Rigler. 1982. Improvements in quantifying the phosphorus concentration in lake water. Canadian Journal of Fisheries and Aquatic Sciences 39:822829.

Prescott, G. W. 1962. Algae of the western Great Lakes area. William C. Brown, Dubuque, Iowa, USA.

. 1978. How to know the freshwater algae. William C. Brown, Dubuque, Iowa, USA.

Pringle, C. 1990. Nutrient spatial heterogeneity: effects on community structure, physiognomy, and diversity of stream algae. Ecology 71:905-920.

Reinertsen, H., A. Jensen, A. Langeland, and Y. Olsen. 1986. Algal competition for phosphorus: the influence of zooplankton and fish. Canadian Journal of Fisheries and Aquatic Sciences 43:1135-1141.

Rhee, G. Y. 1978. Effects of N:P atomic ratios and nitrate limitation on algal growth, cell composition and nitrate uptake. Limnology and Oceanography 23:10-25.

Riber, H. H., and R. G. Wetzel. 1987. Boundary-layer and internal diffusion effects on phosphorus fluxes in lake periphyton. Limnology and Oceanography 32:1181-1194.

Rice, J. A., J. E. Breck, S. M. Bartell, and J. F. Kitchell. 1983. Evaluating the constraints of temperature, activity, and consumption on growth of largemouth bass. Environmental Biology of Fishes 9:263-275.

Roos, P. J. 1983. Dynamics of periphytic communities. Pages 5-10 in R. G. Wetzel, editor. Periphyton of freshwater communities. W. Junk, The Hague, The Netherlands. 
Rosemond, A. D. 1996. Indirect effects of herbivores modify predicted effects of resources and consumption on plant biomass. Pages 149-159 in G. A. Polis and K. O. Winemiller, editors. Food webs: integration of pattern and dynamics. Chapman and Hall, New York, New York, USA.

Rosemond, A. D., P. J. Mulholland, and J. W. Elwood. 1993. Top-down and bottom-up control of stream periphyton: effects of nutrients and herbivores. Ecology 74:1264-1280.

Rychly, J., and B. A. Marina. 1977. The ammonia excretion of trout during a 24-hour period. Aquaculture 11:173-178.

SAS Institute. 1987. SAS user's guide: basics. Version 6.04 SAS Institute, Cary, North Carolina, USA.

Schindler, D. E., S. R. Carpenter, K. L. Cottingham, X. He, J. R. Hodgson, J. F. Kitchell, and P. A. Soranno. 1996 Food web structure and littoral zone coupling to pelagic trophic cascades. Pages 95-105 in G. A. Polis and K. O Winemiller, editors. Food webs: integration of patterns and dynamics. Chapman and Hall, New York, New York, USA

Smith, V. H. 1983. Low nitrogen to phosphorus ratios favor dominance by blue-green algae in lake phytoplankton. Science 221:669-671.

Sommer, U. 1983. Nutrient competition between phytoplankton species in multispecies chemostat experiments. Archiv für Hydrobiologie. Ergebnisse der Limnologie 96:399416.

Steinman, A. D., P. J. Mulholland, and W. R. Hill. 1992. Functional responses associated with growth form in stream algae. Journal of the North American Benthological Society 11:229-243.

Steinman, A. D., P. J. Mulholland, and D. B. Kirschtel. 1991 Interactive effects of nutrient reduction and herbivory on biomass, taxonomic structure, and $\mathrm{P}$ uptake in lotic periphyton communities. Canadian Journal of Fisheries and Aquatic Sciences 48:1951-1959.

Sterner, R. W. 1989. Resource competition during seasonal succession toward dominance by cyanobacteria. Ecology 70:229-245.

Stevenson, R. J., R. Singer, D. A. Roberts, and C. W. Boylen. 1985. Patterns of benthic algal abundance with depth, trophic status, and acidity in poorly buffered New Hampshire lakes. Canadian Journal of Fisheries and Aquatic Sciences 42:1501-1512.

Stewart, A. J. 1987. Responses of stream algae to grazing minnows and nutrients: a field test of interactions. Oecologia (Berlin) 72:1-7.
Strong, D. R. 1992. Are trophic cascades all wet? Differentiation and donor-control in specious ecosystems. Ecology 73:747-754.

Swingle, H. S. 1951. Experiments with various rates of stocking bluegills, Lepomis macrochirus (Rafinesque), and largemouth bass, Micropterus salmoides (Lacepede) in ponds. Transactions of the American Fisheries Society 80: 218-230.

Swingle, H. S., and E. V. Smith. 1940. Experiments on the stocking of fish ponds. Transactions of the North American Wildlife Conference 15:218-230.

Threlkeld, S. T. 1988. Planktivory and planktivore biomass effects on zooplankton, phytoplankton, and the trophic cascade. Limnology and Oceanography 33:1362-1375.

Tilman, D. 1982. Resource competition and community structure. Monographs in Population Biology 17.

Tilman, D., S. Kilham, and P. Kilham. 1982. Phytoplankton community ecology: the role of limiting nutrients. Annual Review of Ecology and Systematics 13:349-372.

Turner, A. M. 1996. Freshwater snails alter habitat use in response to predation. Animal Behaviour 51:747-756.

Underwood, G. J. C. 1991. Growth enhancement of the macrophyte Ceratophyllum demersum in the presence of the snail Planorbis planorbis: the effect of grazing and chemical conditioning. Freshwater Biology 26:325-334.

Vanni, M. J. 1987. Effects of nutrients and zooplankton size on the structure of a phytoplankton community. Ecology 68:624-635.

1996. Nutrient transport and recycling by consumers in lake food webs: implications for algal communities. Pages 81-95 in G. A. Polis and K. O. Winemiller, editors. Food webs: integration of pattern and dynamics. Chapman and Hall, New York, New York, USA.

Vanni, M. J., and D. L. Findlay. 1990. Trophic cascades and phytoplankton community structure. Ecology 71:921-937.

Vollenweider, R. A., editor. 1974. A manual on methods for measuring primary production in aquatic environments. Second edition. International Biology Program Handbook 12. Blackwell Scientific, Oxford, UK.

Wetzel, R. G. 1990. Land-water interfaces: metabolic and limnological indicators. Verhandlungen der Internationale Vereinigung für Theoretische und Angewandte Limnologie 24:6-24.

Whitford, L. A., and G. J. Schumacher. 1973. A manual of the fresh-water algae. Sparks Press, Raleigh, North Carolina, USA. 